Jurnal Syntax Imperatif: Jurnal Ilmu Sosial dan Pendidikan

p-ISSN: 2721-2491 e-ISSN :2721-2246

Vol. 1, No. 4, September 2020

\title{
Transformasi Makna Sabar Bagi Terapis (Studi Fenomenologis di Yayasan Budi Mulya Kecamatan Cililin Kabupaten Bandung Barat)
}

\section{Saepulloh}

Sekolah Tinggi Agama Islam (STAI) Darul Falah Cihampelas Bandung Barat, Indonesia Email: saepullohma33@gmail.com

\begin{abstract}
Abstrak
Autis adalah anak yang memiliki hambatan dalam proses sosial, komunikasi, perilaku dan bahasa. Setiap anak autis memiliki kondisi yang berbeda-beda, untuk kondisi autis berat memiliki perilaku tantrum yang berlebihan, yaitu sering menunjukkan perilaku negatif pada orang-orang di sekitarnya terutama pada para terapis. Oleh sebab itu, dalam mendidik anak autis dibutuhkan kesabaran yang ekstra. Sebagaimana fenomena yang peneliti temukan di YayasanBudi Mulya menunjukkan bahwa beberapa terapis sering mendapatkan perlakuan negatif dari anak-anak autis yang diterapinya. Adapun beberapa bentuk perilaku negatif yaitu meninju, memukul dan mancakar terapis. Untuk itu penelitian ini bertujuan untuk memahami signifikasi sabar bagi masing-masing para terapis. Metode yang digunakan dalam penelitian ini adalah kualitatiffenomenologis. Fenomenologi menekankan pengalaman subjektifitas atau pandangan berfikir yang menekankan pada pengalaman- pengalaman subjektif manusia dan interpretasi-interpretasi dunia subyek. Peneliti menggunakan empat subyek yaitu terapis yang bekerja diYayasan Budi Mulya Kecamatan Cililin Kabupaten Bandung Barat. Metode pengumpulan data memakai wawancara mendalam, observasi dandokumentasi. hasil penelitian memberikan bahwa subjek memaknai sabar: (1) menerima semua syarat, timbul perilau sabar berawal dari rasa sayang serta ketulusan dan tetap tenang dalam menghadapi perilaku anak autis. (2) menerima dengan tulus apapun ujian yang Allah berikan serta selalu berprasangka baik (husnudzon) terhadap seluruh persoalan. (3) bisa menahan diri serta emosi atas sikap negatif dari anak-anak autis, contohnya ketika mereka refleks memukul ataupun melakukan hal negatif lainnya yang bisa menyakiti fisik terapis, untuk tidak membalas perlakuan tersebut. (4) bisa mengatur emosi dengan cara berusaha menekan egonya.
\end{abstract}

Kata kunci: Transformasi; Makna Sabar; Terapis;

\section{Pendahuluan}

Memiliki anak yang normal menjadi dambaan setiap orang tua dan keluarga. Di mana anak normal merupakan anak yang sesuai dengan tahap pertumbuhan dan perkembangan anak. Meggit mendefinisikanperkembangan anak sebagai suatu proses, yaitu anak tumbuh dan mengalami berbagaiperubahan sepanjang hidupnya, perkembangan anak dapat ditentukan secaragenetik serta dipengaruhi dan dimodifikasioleh berbagai faktor lingkungan, sepertinutrisi, kondisi hidup dan segala yang dialamipada setiap tahap kehidupan (Meggit, 2013)

Sementara itu, Rachmayana mengartikan anak berkebutuhan khusus sebagai anak dengan karakteristik tertentuyang berbeda dengan anak pada umum nyatanpa selalu menunjukkan pada ketidakmampuan mental, emosi, atau fisik (Rachmayana, 2013). Anak berkebutuhan khusus adalah autis. Autisme ialah suatu perilaku dimana seorang anak berbuat semaunya sendiri baik cara berfikir maupun berprilaku. Setiap tahun di seluruh dunia, kasus autisme mengalami peningkatan. Data Unescopada tahun 2019 mencatat, sekitar 35 juta orang penyandang autisme di dunia. Artinya bahwa 
rata-rata 6 dari 1.000 orang di dunia mengidap autisme. Di Indonesia menurut BPS 2019 mencapai 66 juta 805 jiwa dengan usia 5-19 tahun, maka dapat diperkirakan jumlah anak autis pada usia 5-19 tahun terdapat 112 ribu anak yang rentang mengalami gejala autis. Beberapa fakta mengenai persoalan penanganan masalah autisme di Indonesia yaitu: kurangnya tenaga terapis yang terlatih, tidak terdeteksinya kasus-kasus autisme secara dini, dan minimnya pengetahuan mengenai autime

Sabar menurut kamus bahasa arab berasal dari kata Shabaro dan Shabaaran yang artinya menahan (Munawwir, 1997). Sedangkan dari Kamus besar Bahasa Indonesia sabar ialah tenang serta tahan menghadapi cobaan, yaitu jika seorang diberi cobaan oleh Allah maka orang tersebut tidak praktis putus harapan, patah hati ataupun murka, serta selalu sabar menghadapi hidup (Lubis, 2012). Sabar ialah menahan diri dari berkeluh kesah dalam menjalankan perintah Allah pada saat menghadapi musibah (Tebba \& Saibani, 2006).

Dalam ilmu tasawuf, sabar dapat diartikan sebagai dorongan seseorang untuk memiliki kesabaran terhadap apa yang dialami, dilihat, didengar, diucapkan dan dirasakan dalam ketentuan Allah sehingga tidak berdaya dalam segala sesuatu (AlKadiri, 2010). Sementara itu menurut ilmu akhlak, sabar adalah akhlaqul karimah yang dibutuhkan oleh seorang muslim dalam masalah dunia dan agama (Abdullah, 2007). Aliah, juga mengungkapkan bahwa sabar ialah sifat tahan menderita atau tahan uji pada mengabdi serta mengikuti perintah Allah Swt dan tahan dari godaan serta cobaan duniawi, yang mendorong sikap berhati-hati pada menghadapi sesuatu .(Hasan \& Aliah, 2008). Sabar juga merupakan madrasah terbesar tempat di manaingin menguji manusia (Al-Qarni, 2004)

Menurut tafsir al-Qur'an, yang dimaksud menguji adalah ujian yang diberikan oleh Allah Swt berupa perintah jihad, untuk dapat membedakan orang yang berjihad dengan sungguh-sungguh, orang yang benar-benar sabar menghadapi cobaan, orang yang beriman sebenarnya dan orang yang beriman palsu atau munafik

Kartono, mendefenisikan terapi sebagai suatu perlakuan dan pengobatan yang ditunjukan pada penyembuhan satu kondisi patologis (Kartono, 2011).

Adapun macam-macam terapi autis menurut Danuatmaja, antara lain : terapi home program, terapi perilaku, terapi kaufan dan son-rise, terapi okupasi, terapi bermain, terapi sensori integrasi, terapi wicara, terapi biomedis dan terapi medika mentosa (Danuatmaja \& Rozaline, 2003)

Kegiatan terapi autis yang terdapat di Yayasan Budi Mulya Kabupaten Bandung Barat adalah terapi interaksi sosialterdiri dari senam gembira dan bermainbersama, terapiterapi perilaku, terapi okupasi, terapi sensoriintegrasi, terapi musik, terapi floor time, terapi wicara, dan terapi bina diri (Wawancara dan observasi 3 Febuari 2020).

Berdasarkan hasil observasi danwawancara yang dilakukan oleh peneliti padatanggal 3-10 Maret 2020, peneliti melihatterdapat semua indikator anak autis yangterdapat diYayasan Budi Mulya Kabupaten Bandung Baratmulai dari indikator autisberat, autis sedang dan autis ringan. Di manasetiap indikator autis memiliki perilaku yangberbeda-beda. Anak autis yang tergolongsebagai autis berat memiliki prilaku tantrum yang tidak dapat dikendalikan, seperti: tiba-tiba mengamuk, memukul, menggigit, menampar, menyakiti diri sendiri dan menyakiti orang lain. Sehingga para terapis yang bekerja di Yayasan Budi Mulya Kabupaten Bandung Barat harus memiliki kesabaran yang sangat tinggi ketika anak tiba-tiba tantrum. Sebagaimana hal ini diungkapkan oleh terapisberinisial IZ, yaitu : “.....disini walaupun kena tinju sabar, 
dimiliki oleh para terapis, karena anak autis pokoknya kalau Melihat AL yang besare harus sabar. (Wawancara dan observasi 3 Febuari 2020).

Sedangkan anak autis yang termasukdalam indikator autis sedang dan ringan memiliki perilaku seperti : hipoaktif, gangguan prilaku, intelegensi di bawah rata-rata dan tidak bisa fokus belajar. Hal ini juga dibutuhkan kesabaran bagi terapis, namun tidak menuntut sabar yang terlalu tinggi, karena anak autis tidak menunjukkan kekerasan fisik, melainkan sabar untuk menahan emosi saja. Sebagaimana hal inijuga diungkapkan oleh salah satu terapisberinisial D, yaitu: “.....Kalau anak autis ini susah pak, banyaklah maen-maennya, kalau tidak kita harus sabar, kalau tidak sabar emosi kita tidak akan terkendali, karena itu sabar itu sangat perlu". (Wawancara, 5 Maret 2020). Dengan demikian, sabar sangat dibutuhkan dan sifatnya sangat uregenoleh para terapis. Karena anak autis memiliki perilaku yang sangat berbeda dengan anak normal.

Perilaku anak autis ada dua, yaitu: perilaku yang dan deficient (kekurangan). Perilaku yangexcessive (berlebihan) excessive seperti: tantrum, agresive, Self-abuse (melukai diri sendiri), membuat berantakan dan stimulasi diri. Begitu juga dengan perilaku deficient, seperti: gangguan bicara misalnya jika ditanya namamu siapa? Maka anak autis akan mengulangi kata-kata tersebut dengan sama persis, dalam psikologi gangguan tersebut dinamakan ekolalia (membeo) (Rachmayana, 2013)

Adapun hasil wawancara yang Adapun hasil wawancara yang terapis berinisial IK di Yayasan Budi Mulya Kabupaten Bandung Barat menyatakan bahwa sabar adalah salah satu syarat utama yang harus dimiliki oleh para terapis (wawancara 3 Febuari 2020).

\section{Metode Penelitian}

Penelitian ini menggunakan metode kualitatif dengan desain fenomenologi. Meleong mengartikan penelitian kualitatif menjadi penelitian yang bermaksud untuk memahami kenyataan tentang apa yang dialami oleh subjek penelitian secara keseluruhan serta menggambarkan pada bentuk istilah-kata serta bahasa, pada suatu konteks spesifik yang alamiah serta menggunakan memanfaatkan berbagai metode alamiah. (Moleong, 2013)

\section{Hasil dan Pembahasan}

\section{A. Hasil}

Pengalaman sabar yang berkaitan dengan kegiatan terapi autis adalah kejadiankejadian unik yang dialami oleh para terapis. Semua kejadian unik yang dialami terapis seperti dipukul, digigit, dicakar, diludahi jilbab ditarik hingga terlepas dan lain sebagainya. Pengalaman-pengalaman dari kejadian unik yang sering dialami oleh subjek penelitian, dapat menjadikan subjek memiliki pribadi sabar. Peran penting dalam membimbing ataupun mendidik anak autis telah dinyatakan oleh Safaria bahwa untuk membimbing anak dengan gangguan autism bukanlah hal yang mudah, karena membutuhkan banyak kesabaran, keteguhan hati, ketekunan dan energi yang besar (Safaria, 2005).

Al-Ghazali membagi karakter sabar menjadi dua aspek, yaitu aspek fisik dan psikis. Aspek fisik artinya sabar dengan cara menahan diri dari kesulitan dan kelelahan badan dalam menjalankan perbuatan yang baik. Sedangkan aspek psikis yaitu sabar dengan cara menahan diri dari tuntutan hawa nafsu (Mujib, 2006). 
Transformasi sabar yang telah dijelaskan oleh peneliti sebelumnya disebut dengan episode transformasi sabartema yang muncul dalam episode transformasi sabar, pertama yaitu: subjek mengalami hubungan yang dekat dengan Allah Swt, kedua, subjek memahami pentingnya sabar dalam kehidupan, ketiga subjek mampu memaknai sabar sebagai terapis, dan terakhir adanya hubungan yang baik antara profesi sebagai terapis dan kehidupan sehari-hari.

Tema-tema yang muncul dalam episode ini ternyata sesuai dengan karakteristik para terapis sebagaimana dijelaskan oleh Corey, antara lain: menerima perasaan kuat yang palsu, bersedia mengambil risiko, memiliki keberanian untuk bertindak, memiliki rasa empati, memiliki sifat selaras, tulus, jujur dan toleran (Corey, 2009).

Pada episode transformasi sabar ini menunjukkan bahwa pribadi sabar sebagai terapis mengalami perkembangan dalam diri subjek. Sehingga penelitian ini menyimpulkan bahwa subjek yang bekerja sebagai terapis mengalami transformasi sabar dari sabar yang biasa/umum menuju pada tingkatan sabar yang lebih tinggi/profesional.

Langkah-langkah untuk menemukan makna sabar bagi para terapis di atas telah dijelaskan oleh Ubaid, yaitu ada beberapa komponen untuk menentukan transformasi dari pribadi sabar yang tidak bermakna menuju pribadi sabar yang lebih bermakna, diantaranya menahan diri dari berkeluh kesah, menahan lisan dari mengadu, dan menahan anggota badan melukai diri (Uliya Ali Ubaid, 2012).

Tema-tema pengalaman transformasi sabar yang dibahas pada bab ini merupakan hasil analisis pada setiap subjek dan informan tahu serta hasil observasi. Tema-tema tersebut akan tersaji sesuai dengan pengalaman subjek satu persatu yang kemudian akan terdapat beberapa trianggulasi (pembanding) data melalui informan (IT) atau sesuai hasil observasi yang sudah dilakukan oleh peneliti.

\section{B. Pembahasan}

Tema-tema dimulai dari kehidupan subjek sebelum menjadi terapis, kemudian bagaimana subjek dapat bergabung menjadi terapis dan pengalaman-pengalaman yang menuntut terapis untuk sabar hingga akhirnya terapis dapat merasakan perubahan setelah sekian tahun menjadi terapis. Untuk mempermudah memahaminya maka peneliti hanya menyajikan intisari dari temuan penelitian sebagai berikut:

\section{Pengalaman IZ}

"Kembali lagi ke diri kita masing- masing, Menerima, ikhlas." IZ menjelaskan makna sabar bagi paraterapis, yaitu menerima semua kondisi selama proses mengajar anak autis, AL tidak pernah memilih anak untuk diterapi, melainkan IZhanya menerima apapun kondisi anak autis tersebut. Sabar muncul berawal dari rasa sayang dan ketulusan serta tetap tenang dalam menghadapi perilaku anak autis. Berikut ungkapan IZ:

\section{Pengalaman SR}

SR memaknai sabar untuk diri sendiri maupun sebagai terapis yaitu menerima dengan ikhlas apapun ujian yang Allah Swt berikan dan selalu berprasangka baik (husnudzon) terhadap semua masalah (Wawancara, 3 Februari 2020). 


\section{Pengalaman HR}

"Ya sabar itu memenej sekecil-kecil mungkin emosi yang ada di dalam diri, ego kita harus ditekan" (Wawancara, 3 Februari 2020). HR mengungkapkan bahwa para terapis harus dapat menahan diri dan emosi atas perilaku negatif dari anak-anak autis. Saat anak autis secara refleks memukul ataupun melakukan hal negatif lainnya yang dapat menyakiti fisik terapis, untuk tidak membalas perlakuan tersebut. Adapun cara HR menahan emosinya ketika anak menyakiti fisik, yaitu dengan memahami setiap kondisi anak, dengan begitu HR dapat memahami bahwa anak tersebut tidak mengerti apa yang telah dilakukannya. Sehingga HR memaknai sabar dengan menahan rasa sakit akibat perlakuan negatif yang di berikan oleh anak. Sebagaimana HR mengungkapkan :

"Kuncinya itu tadi apa ketika kita mau marah atau mau apa, kita itu ingat bahwa anak ini tidak paham dan tidak mengerti mangkanya kita apa kuncinya harus lebih sabar, misalnya di pukul kita harus menahan karena mereka itu tidak tahu, tidak mengertikan apa yang dilakukan, nah kuncinya itu." (Wawancara, 3 Februari 2020).

\section{Pengalaman IK}

IK mengungkapkan bahwa makna sabar menurutnya adalah saat diriya dapat mengatur emosi dengan cara berusaha menekan egonya, dengan demikian IK dapat mengontrol emosinya sebaik mungkin Wawancara, 3 Februari 2020).

\section{Kesimpulan}

Dari pembahasan di atas bisa disimpulkan bahwa subjek memaknai sabar itu menerima seluruh kondisi, muncul perilau sabar berawal dari rasa saying serta ketulusan dan tetap tenang dalam menghadapi perilaku anak autis. ikhlas apapun ujian yang Allah berikan serta selalu berprasangka baik (husnudzon) terhadap seluruh persoalan. bisa menahan diri serta emosi atas sikap negatif dari anak-anak autis, contohnya ketika mereka refleks memukul ataupun melakukan hal negatif lainnya yang bisa menyakiti fisik terapis, untuk tidak membalas perlakuan tadi. Serta dapat mengatur emosi dengancara berusaha menekan egonya. Memahami proses secara utuh dapat dipahami bahwa para terapis mengalami tranformasi sabar dari pribadi sabar yang „umum ${ }^{\text {ee }}$ menuju pribadi sabar dengan cara yang lebih tinggi professional. 
Saepulloh

\section{BIBLOGRAFI}

Abdullah, Y. (2007). Studi Akhlak dalam Perspektif al Quran. Jakarta: Amzah.

Al-Kadiri, C. A. (2010). 8 Langkah Mencapai Ma'rifatullah / Choirul Anam Al-Kadiri (Jakarta). Amzah.

Al-Qarni. (2004). Jagalah Allah, Allah Menjagamu. Jakarta: Darul Haq.

Corey, G. (2009). Teori dan praktek konseling dan psikoterapi. Bandung: PT Refika Aditama.

Danuatmaja, B., \& Rozaline, H. (2003). Terapi anak autis di rumah. Puspa Swara.

Hasan, A. B. P., \& Aliah, B. (2008). Psikologi Perkembangan Islam: Menyingkap Rentang Kehidupan Manusia dari Pra kelahiran hingga Pasca kematian. Rajagrafindo.

Kartono, K. (2011). Kamus Lengkap Psikologi JP Chaplin. Jakarta: Rajawali Pers.

Lubis, P. (2012). Kamus Besar Bahasa Indonesia Pusat Bahasa Indonesia. Jakarta: PT Gramedia Pustaka Utama.

Meggit, C. (2013). Memahami perkembangan anak. Jakarta: PT Indeks.

Moleong, L. J. (2013). Metode Penelitian Kualitatif, Bandung: Remaja Rosdakarya. Mosal.

Mujib, H. A. (2006). Kepribadian dalam psikologi Islam. PT Rajagrafindo Persada.

Munawwir, A. W. (1997). Kamus Al-Munawwir Arab-Indonesia. Surabaya: Pustaka Progresif.

Rachmayana, D. (2013). Diantara pendidikan luar biasa menuju anak masa depan yang inklusif. Jakarta: PT LUXIMA METRO MEDIA.

Tebba, S., \& Saibani, A. (2006). Bekerja dengan hati: bagaimana membangun etos kerja dengan spiritualitas religius. Bee Media Indonesia.

Uliya Ali Ubaid. (2012). Sabar dan Syukur Gerbang Kebahagiaan Dunia Akhirat. Jakarta: Bumi Aksara. 